\title{
Systematic review and meta-analysis of selected toxicities of approved $A L K$ inhibitors in metastatic non-small cell lung cancer
}

\author{
Rubens Barros Costa ${ }^{1}$, Ricardo L.B. Costa ${ }^{2}$, Sarah M. Talamantes ${ }^{3}$, Jason B. Kaplan ${ }^{1}$, \\ Manali A. Bhave ${ }^{1}$, Alfred Rademaker ${ }^{4}$, Corinne Miller ${ }^{5}$, Benedito A. Carneiro ${ }^{6}$, \\ Devalingam Mahalingam ${ }^{1}$ and Young Kwang Chae ${ }^{1}$ \\ ${ }^{1}$ Developmental Therapeutics Program, Northwestern University, Chicago, IL, USA \\ ${ }^{2}$ Department of Breast Oncology, Lee Moffitt Cancer Center, Tampa, USA \\ ${ }^{3}$ Northwestern University, Feinberg School of Medicine, Chicago, IL, USA \\ ${ }^{4}$ Northwestern University, Department of Preventive Medicine, Chicago, IL, USA \\ ${ }^{5}$ Galter Health Sciences Library, Northwestern University, Chicago, IL, USA \\ ${ }^{6}$ Life Span Cancer Institute, Providence, RI, USA \\ Correspondence to: Rubens Barros Costa, email: barros4@yahoo.com \\ Keywords: crizotinib; ceritinib; alectinib; brigatinib; anaplastic lymphoma kinase \\ Received: January 20, $2018 \quad$ Accepted: April 04, $2018 \quad$ Published: April 24, 2018 \\ Copyright: Costa et al. This is an open-access article distributed under the terms of the Creative Commons Attribution License 3.0 (CC BY \\ 3.0), which permits unrestricted use, distribution, and reproduction in any medium, provided the original author and source are credited.
}

ABSTRACT

Introduction: Anaplastic lymphoma kinase (ALK) inhibitors are the mainstay treatment for patients with non-small cell lung carcinoma (NSCLC) harboring a rearrangement of the ALK gene or the ROS1 oncogenes. With the recent publication of pivotal trials leading to the approval of these compounds in different indications, their toxicity profile warrants an update.

Materials and Methods: A systematic literature search was performed in July 2017. Studies evaluating US FDA approved doses of one of the following ALK inhibitors: Crizotinib, Ceritinib, Alectinib or Brigatinib as monotherapy were included. Data were analyzed using random effects meta-analysis for absolute risks (AR), study heterogeneity, publication bias and differences among treatments.

Results: Fifteen trials with a total of 2,005 patients with evaluable toxicity data were included in this report. There was significant heterogeneity amongst different studies. The pooled AR of death and severe adverse events were $0.5 \%$ and $34.5 \%$, respectively. Grade 3/4 nausea, vomiting, diarrhea, and constipation were uncommon: $2.6 \%, 2.5 \%, 2.7 \%, 1.2 \%$, respectively.

Conclusions: ALK inhibitors have an acceptable safety profile with a low risk of treatment-related deaths. Important differences in toxicity profile were detected amongst the different drugs.

\section{INTRODUCTION}

Lung cancer is the most common cause of cancer death in men and the second leading cause of cancer death in women worldwide. Non-small cell lung carcinoma (NSCLC) harboring rearrangements of the anaplastic lymphoma kinase $(A L K)$ gene and the ROS1 oncogene constitute a unique molecular subgroup of this patient population. They comprise approximately $5 \%$ and $1 \%$ of all the NSCLC cases, respectively $[1,2]$. ALK inhibitors may represent an important potential treatment in this setting.

The early signal of efficacy noted in this class of agents led regulatory agencies to fast track clinical development from Phase 1 dose-finding studies straight to phase 3 trials, resulting in less toxicity data than would have been attained otherwise [3-5].

Crizotinib was the first-in-class $A L K$ inhibitor developed and evaluated in patients with NSCLC harboring $A L K$ rearrangements. Utilizing medicinal 
chemistry and rational design, different groups have then been successful in the synthesis of novel, selective and potent $A L K$ inhibitors with acceptable and consistent pharmacokinetic and pharmacodynamics profiles displaying strong in vivo efficacy in $A L K$-positive NSCLC xenograft models at well-tolerated doses. This has led to further development of these drugs [6]. Differences in the chemical structures amongst the $A L K$ inhibitors may result in different toxicity profiles and efficacy [7].

Multiple $A L K$ inhibitors including Crizotinib, Ceritinib, Alectinib, and Brigatinib have shown efficacy in the subset of $A L K$-rearranged NSCLC in the first and subsequent lines of therapy [3-5, 8-16]. Crizotinib was compared to chemotherapy in previously treated patients, with a median Progression- Free Survival (PFS) of 7.7 months in the Crizotinib group and 3.0 months in the chemotherapy group (95\% confidence interval [CI], 0.37 to $0.64 ; P<0.001)$. Overall response rates (ORR) were higher in the Crizotinib group than in the chemotherapy group: $65 \%$ with Crizotinib versus $20 \%$ with chemotherapy [4]. In the treatment-naïve setting, PFS was significantly longer with Crizotinib than with chemotherapy (10.9 months vs. 7.0 months, 95\% CI, 0.35 to $0.60 ; P<0.001)$. The ORR was significantly higher with Crizotinib than with chemotherapy (74\% versus $45 \%,(P<0.001))$ [3]. A phase 3 trial compared Ceritinib to standard chemotherapy in patients who progressed following Crizotinib and a platinum-based doublet. Ceritinib showed a significant improvement in median PFS compared to chemotherapy $(5 \cdot 4$ months for Ceritinib compared to 1.6 months for chemotherapy). ORR were $7 \%$ for the chemotherapy group as compared with $39 \%$ for the Ceritinib group, indicating that $A L K$ rearrangements are predictive of benefit to targeted therapy after progression on first line treatment [11]. Resistance mechanisms including mutation of the kinase domain, amplification of the gene copy number, bypass signaling, transformation to small cell lung cancer, have been previously described [17].

The kinase domains of both $A L K$ and ROS1 share significant amino acid homology within the ATPbinding sites [18]. Pre-clinical data support the use of $A L K$ inhibitors as a potential target for ROS1 mutation in NSCLC. For instance, Crizotinib has been shown to induce anti-proliferative activity, inhibit putative downstream targets, and induce apoptosis in ALK and ROS1translocated cell lines [19]. Crizotinib showed a median PFS of 19.2 months and ORR of $72 \%$ in the expansion cohort of the pivotal phase I trial of patients with NSCLC with tumors harboring a ROS1 fusion. In a phase 2 trial, Ceritinib showed a median PFS of 9.3 months for all patients and 19.3 months for Crizotinib-naive patients with an ORR of $62 \%[20,21]$. In a retrospective analysis of ROS1 fusion-positive patients, Crizotinib showed a higher overall response rate (ORR); disease control rate (DCR) and longer PFS (PFS) compared to pemetrexed and non-pemetrexed based chemotherapy. ORR, DCR, and PFS were $80 \%, 90.0 \%$, and 294 days, respectively, for Crizotinib, 40.8\%, 71.4\%, and 179 days, respectively, for pemetrexed chemotherapy, and $25.0 \%, 47.7 \%$, and 110 days, respectively, for non-pemetrexed chemotherapy. Taken together, these data suggest superior efficacy of the $A L K$ inhibitors compared to chemotherapy in this molecularly distinct subgroup of patients [22].

The National Comprehensive Cancer Network guidelines recommend testing for $A L K$ rearrangement and ROS1 fusion for individuals with metastatic NSCLC since $A L K$ inhibitors are recommended for the treatment of metastatic NSCLC in the first and second lines settings. Crizotinib is considered the first choice in the treatment of $R O S 1$ rearrangement-positive metastatic NSCLC [23].

The purpose of this systematic review and metaanalysis is to update the side effect profile of $A L K$ inhibitors in NSCLC with a focus in select adverse events, considering the recent approvals and very recent publication of full manuscripts of respective clinical trials. Recent toxicity data may be used as tool for the selection of ALK inhibitors.

\section{MATERIALS AND METHODS}

\section{Search strategy}

A systematic literature search was performed in July 2017 by a medical librarian in adherence with the Preferred Reporting Items for Systematic Reviews and Meta-Analyses (PRISMA) statement [24, 25]. Subject headings and keywords were used to locate literature in the English language on the use of select $A L K$ inhibitors (Crizotinib; Ceritinib; Alectinib; Brigatinib) in NonSmall Cell Lung Cancer in MEDLINE via PubMed 1946July 2017, EMBASE 1947- July 2017, and Cochrane Library. The full search strategy for PubMed is provided as supplementary data. The database was searched for articles published on or before July 24, 2017. All publication dates were included. Only fully published manuscripts were included in this analysis.

\section{Selection of trials and data extraction}

Inclusion criteria were as follows: 1- Phase 1 expansion-cohort, phase 2, phase 3 or the control arm of a Phase 3 trial using the FDA-approved dose of the particular $A L K$ inhibitor (Crizotinib $250 \mathrm{mg}$ twice daily, Ceritinib $750 \mathrm{mg}$ once daily, Alectinib $600 \mathrm{mg}$ twice daily, Brigatinib $180 \mathrm{mg}$ once daily) for the treatment of metastatic $A L K$-rearranged or metastatic/recurrent ROSrearranged NSCLC; 2- English language. Pediatric or dose-finding Phase I clinical trials were excluded. Studies or study arms that used non-FDA approved doses were also excluded (e.g., Alectinib $300 \mathrm{mg}$ twice daily and/or Brigatinib $90 \mathrm{mg}$ once daily). Other studies using $A L K$ 
inhibitors in earlier development such as Lorlatinib or entrectinib were also excluded. Each publication was reviewed, and in cases of duplicate publication, only the most complete, recent and updated report of a clinical trial was included in this meta-analysis.

For publications meeting inclusion criteria, the following data were extracted: the total number of individuals evaluable for toxicity, number of all grade adverse events (AE), number of grade 3 and 4 AEs, number of deaths related to study drug, and number of discontinuation of treatment due to AEs. Additionally, the number of select grade 3 and 4 AEs were reported [i.e., nausea, vomiting, constipation, diarrhea, fatigue, ILD (interstitial lung disease), QT prolongation]. The relationship between AEs and treatment administration (i.e., treatment-related AEs vs. all-causality) was also documented. The data extraction was performed primarily by the first author (R.B.C.) and subsequently was reviewed by another coauthor (S.M.T.).

\section{Statistical methods}

Meta-analyses were conducted using one-sample proportions to obtain random effects, estimates of toxicity rates and $95 \%$ confidence intervals. Heterogeneity was assessed by the $Q$ chi square statistic [26]. The percent of total variance due to study heterogeneity was estimated using the I squared $\left(\mathrm{I}^{2}\right)$ statistic. Heterogeneity across treatment types was assessed using the betweengroup $Q$ statistic [27]. Publication bias was evaluated using Egger's test [28]. Analyses were conducted using Comprehensive Meta-Analysis software package (Comprehensive Meta-Analysis, Version 3.3.070, 2014, Biostatic; Englewood NJ).

\section{RESULTS}

\section{Study inclusion and characteristics}

Our search strategy yielded 5311 entries through PubMed, EMBASE, and Cochrane combined. 1134 duplicates were initially removed with the deduplication tools in EndNote and Covidence. After examining titles and abstracts, 4158 more entries were excluded. Studies excludedare shown in Figure 1. Fifteen studies met the inclusion criteria and data were extracted. Details of studies selected are described in Table 1. Six studies evaluated Crizotinib; three studies evaluated Alectinib; five studies evaluated Ceritinib; one study evaluated Brigatinib. One of the manuscripts reported the use of Crizotinib for the treatment of ROS1 positive metastatic NSCLC. A different manuscript reported the use of Ceritinib for ROS1 positive metastatic and/or recurrent NSCLC. The remainder of the manuscripts used one of the compounds in the treatment of $A L K$ positive metastatic and or recurrent NSCLC.

\section{Description of study participants}

A total of 2005 individuals were evaluable for toxicity in all fifteen studies. Only 82 patients had tumors harboring ROS1 aberrations. The median age at study entry was 54.6 years. All of the patients had either stage IIIB or stage IV (de novo vs. recurrent) disease. Approximately $8.5 \%$ of the patients accrued in these trials had ECOG Performance Status $\geq 2$.

\section{Study-to-study heterogeneity and publication bias}

There was significant inter-study heterogeneity for most toxicities. Heterogeneity $\mathrm{I}^{2}$ statistics for any grade, any serious, grade $3-4$ AE were as follows: $36.5 \% ; 82.6 \%$, and $96.1 \%$, respectively. Egger's test showed publication bias for many toxicities.

\section{Number of all-grade, grade 3/4 and serious AEs, number of treatment related deaths, and number of patients who discontinued treatment due to toxicity across different studies}

Adverse events were classified and graded according to the Common Terminology Criteria for Adverse Events, version 3.0 or version 4.0. Safety data across the studies were not reported in a uniform fashion. Data were missing for some of the endpoint analyzed in this report. Five out the fifteen studies did not report the number of total AEs. Seven did not report the total number of grade 3 and 4 AEs. Six did not reports serious AE. One study reported an aggregate of grade 3-5 toxicities. Thirteen studies reported the number of patients who experienced an AE. Data were missing for any-grade, grade 3 and 4, serious AEs for 2 studies which reported the total number of AEs. The other studies reported the number of patients who experienced an AE.

Absolute toxicity rates and results of the random effects meta-analysis of each toxicity rate are summarized in Table 2. Toxicity rates for any AE, any serious AE, and grade 3/4 AE were as follows: 98.4\% (95\% CI, 96.9-99.2), $34.5 \%$ (95\% CI, 28.1-41.6), and 64\% (95\% CI, 47.1-78), respectively. All fifteen studies reported the number of patients who discontinued treatment due to toxicities. The pooled AR of discontinuation for all four $A L K$ inhibitors (Crizotinib, Alectinib, Ceritinib, Brigatinib) due to toxicity was approximately $8.2 \%$. All 15 studies described reported treatment-related death rates. Only, 10 treatment-related casualties were reported and were considered deaths due to the use of one of the drugs by the investigators. Causes of death included the following: 1 case of bowel perforation, 1 case of unspecified hemorrhage, 1 case of cardiac arrhythmia, 4 cases of interstitial lung disease/ pneumonitis; 1 case of multiorgan failure; 2 cases of treatment-related deaths not otherwise specified. For all the of studies, the authors made an effort to make a 
Table 1: Characteristics of included trials

\begin{tabular}{|c|c|c|c|c|c|c|c|c|}
\hline $\begin{array}{l}\text { Study } \\
\text { Author }\end{array}$ & PMID & Study Phase & Tumor Type & ALK inhibitor dose & $\begin{array}{l}\text { Number of patients } \\
\text { with } E C O G P S \geq 2\end{array}$ & $\begin{array}{l}\text { Number of patients } \\
\text { evaluable for toxicity }\end{array}$ & $\begin{array}{l}\text { Median follow-up } \\
\text { time (months) }\end{array}$ & $\begin{array}{l}\text { NCI CTCAE } \\
\text { version }\end{array}$ \\
\hline Kim & 28475456 & 2 & $\begin{array}{l}\text { NSCLC-ALK } \\
\text { positive }\end{array}$ & Brigatinib 180 mg QD & 9 & 110 & 8.3 & 4 \\
\hline Peters & 28586279 & 3 & $\begin{array}{l}\text { NSCLC-ALK } \\
\text { positive }\end{array}$ & Alectinib 600 mg BID & 10 & 152 & 18.6 & 4 \\
\hline Peters & 28586279 & 3 & $\begin{array}{l}\text { NSCLC-ALK } \\
\text { positive }\end{array}$ & Crizotinib $250 \mathrm{mg}$ BID & 10 & 151 & 17.6 & 4 \\
\hline Shaw & 26708155 & 2 & $\begin{array}{l}\text { NSCLC-ALK } \\
\text { positive }\end{array}$ & Alectinib $600 \mathrm{mg}$ BID & 9 & 86 & 9.9 & 4 \\
\hline OU & 26598747 & 2 & $\begin{array}{l}\text { NSCLC-ALK } \\
\text { positive }\end{array}$ & Alectinib 600 mg BID & 13 & 138 & 10.96 & 4 \\
\hline Kim & 26973324 & $\begin{array}{l}\text { 1(expansion- } \\
\text { cohort) }\end{array}$ & $\begin{array}{l}\text { NSCLC-ALK } \\
\text { positive }\end{array}$ & Ceritinib $750 \mathrm{mg}$ QD & 28 & 246 & 11.1 & 4 \\
\hline Crino & 27432917 & 2 & $\begin{array}{l}\text { NSCLC- ALK } \\
\text { positive }\end{array}$ & Ceritinib $750 \mathrm{mg}$ QD & 20 & 140 & 11.3 & 4 \\
\hline Shaw & 28602779 & 3 & $\begin{array}{l}\text { NSCLC-ALK } \\
\text { positive }\end{array}$ & Ceritinib $750 \mathrm{mg}$ QD & 9 & 115 & 16.6 & 4 \\
\hline Lim & 28520527 & 2 & $\begin{array}{l}\text { NSCLC- ROS } 1 \\
\text { positive }\end{array}$ & Ceritinib $750 \mathrm{mg}$ QD & 4 & 32 & 14 & 4 \\
\hline Soria & 28126333 & 3 & $\begin{array}{l}\text { NSCLC- ALK } \\
\text { positive }\end{array}$ & Ceritinib $750 \mathrm{mg}$ QD & 13 & 189 & 19.2 & 4 \\
\hline Shaw & 25264305 & $\begin{array}{l}\text { 1(expansion- } \\
\text { cohort) }\end{array}$ & $\begin{array}{l}\text { NSCLC- ROS } 1 \\
\text { positive }\end{array}$ & Crizotinib $250 \mathrm{mg}$ BID & 1 & 50 & 16.4 & 3 \\
\hline Solomon & 25470694 & 3 & $\begin{array}{l}\text { NSCLC-ALK } \\
\text { positive }\end{array}$ & Crizotinib $250 \mathrm{mg}$ BID & 10 & 171 & 17.4 & 4 \\
\hline Camidge & 22954507 & $\begin{array}{l}\text { 1(expansion } \\
\text {-cohort) }\end{array}$ & $\begin{array}{l}\text { NSCLC-ALK } \\
\text { positive }\end{array}$ & Crizotinib $250 \mathrm{mg}$ BID & 18 & 149 & 16.3 & 3 \\
\hline Shaw & 23724913 & 3 & $\begin{array}{l}\text { NSCLC-ALK } \\
\text { positive }\end{array}$ & Crizotinib $250 \mathrm{mg}$ BID & 16 & 172 & 12.2 & 4 \\
\hline Hida & 28501140 & 3 & $\begin{array}{l}\text { NSCLC-ALK } \\
\text { positive }\end{array}$ & Crizotinib $250 \mathrm{mg}$ BID & 2 & 104 & 12.2 & 4 \\
\hline
\end{tabular}

distinction between grade 5 toxicity and treatment-related deaths. Treatment-related deaths represented less than $0.5 \%$ of the population evaluable for toxicity in this report.

\section{Number of all-grade and grade $3 / 4$ gastro intestinal (GI) and other selected toxicities}

The four most common GI all-grade toxicities were diarrhea, nausea, vomiting, and constipation, respectively. They were consistently reported across all studies. Only one study did not report the rates of constipation. Estimated AR for all grade diarrhea, nausea, vomiting and constipation were: diarrhea 54\% (95\% CI, 41-68), nausea 52\% (95\% CI, 40-63), vomiting 38\% (95\% CI, 29-48) and constipation $32 \%$ (95\% CI, 27-36). The risk for grade 3/4 diarrhea, nausea, vomiting and constipation were as follows: diarrhea 2.6\% (95\% CI, 2-4); nausea 2.5\% (95\% CI, 2-4); vomiting $2.7 \%$ (95\% CI, 2-4); constipation $1.2 \%$ (95\% CI, $1-2)$. The estimated AR for any visual disturbance was of $43.5 \%$ in only 4 of the crizotinib studies. One case of visual disturbance occurred with the use of ceritinib and no cases occurred with the use of Alectinib or Brigatinib. Grade 3/4 QTcB prolongation was reported in 11 of the studies included in the analysis, with a random-effect pooled risk of $2.1 \%(95 \%$ CI, 1-4). Grade 3/4 ILD was reported in 9 studies occurring in a total of seventeen individuals. Grade 3/4 ALT and AST elevations were infrequent events. Grade $3 / 4$ fatigue was reported in 14 of the 15 studies, with a random-effect pooled AR of 3.2\% (95\% CI, 2-5).

\section{All grade, grade 3/4, serious AE toxicity rates across different treatment groups}

Differences in AR of any grade, grade 3/4, serious AE were detected amongst different treatment groups (Table 3). There were also differences amongst the selected AEs in relation to GI toxicity including nausea, vomiting and diarrhea. Ceritinib was associated with a high rate of nausea, vomiting and diarrhea with a low chance of Grade 3/4 toxicity. QTcB prolongation was rare. A more detailed description of risk of selected toxicities according to treatment group is shown in Table 3 .

\section{DISCUSSION}

In this analysis, all four of the approved $A L K$ inhibitors have shown acceptable toxicity profiles with the majority 
of AEs being either grade 1 or 2 . Fewer than $0.5 \%$ of the pooled population with evaluable toxicity were noted to have treatment-related deaths $(n=10)$. The combined rate of discontinuation for all of the 4 drugs was approximately $8.2 \%$.

Furthermore, we analyzed the AR of selected AEs between studies and amongst the 4 US FDA-approved
$A L K$ inhibitors. It is important to highlight a few of these toxicities including, nausea, vomiting, constipation, and diarrhea, as they were frequent (predominantly grade 1 or 2). The risk of grade $3 / 4$ nausea, vomiting, diarrhea, and constipation were $2.5 \%, 2.7 \%, 2.6 \%$, and $1.2 \%$ respectively. They were consistently reported across
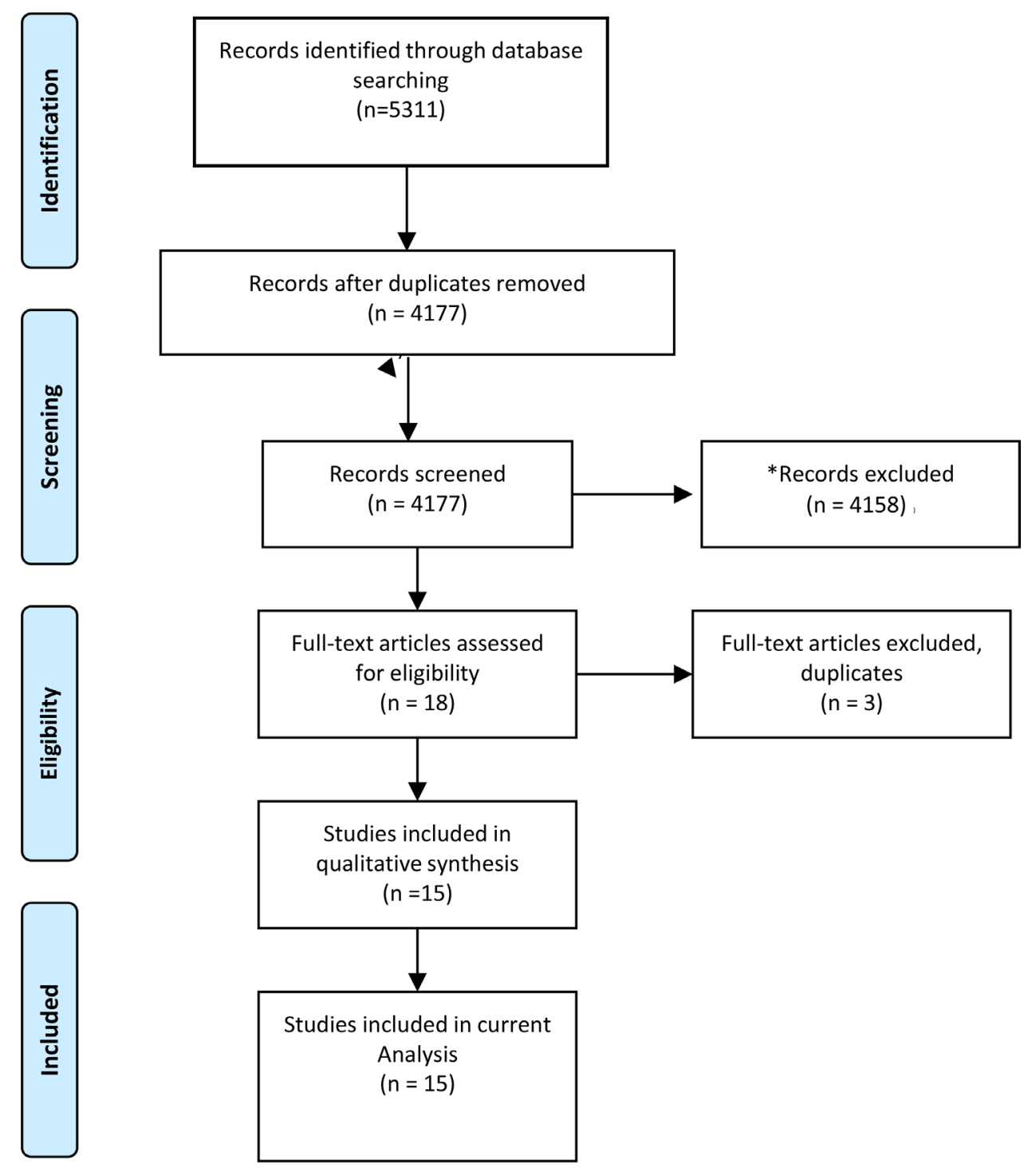

1 - Observational, Pre-Clinical, Subgroup Analysis ( $n=960$ )

2 - Abstract, Commentary, Correspondence, Report, Correction ( $n=1172)$

3 - Systematic Review, Meta-Analysis, Pooled Analysis( $n=43)$

4 - Retrospective, Chart review ( $n=364$ )

5 - Review, Case report, Case series $(n=1410)$

6 - Guidelines( $n=26)$

7 - not related to the subject of interest $(n=59)$

8 - Conference report( $n=32)$

9 - Phase 1 Dose escalation, Pediatric Trial, Dosage used not FDA approved ( $n=92)$

Figure 1: Flow diagram - study selection. 
Table 2: Meta analysis summary of adverse events

\begin{tabular}{|c|c|c|c|c|c|c|c|}
\hline $\mathbf{A E}$ & $\begin{array}{c}\text { Number } \\
\text { of studies }\end{array}$ & $\begin{array}{c}\text { Number of } \\
\text { evaluable patients }\end{array}$ & $\begin{array}{c}\text { Number of } \\
\text { patients with } A E\end{array}$ & $\begin{array}{l}\text { Random effects } \\
\text { toxicity rate (\%) }\end{array}$ & $\begin{array}{c}\text { Random effects } 95 \% \\
\text { confidence interval }\end{array}$ & $\begin{array}{c}\text { Heterogeneity } \\
p \text {-value }\end{array}$ & $\mathbf{I}^{2}$ \\
\hline Any $\mathbf{A E}$ & 10 & 1450 & 1435 & 98.4 & $96.9-99.2$ & 0.12 & 36.5 \\
\hline Any Serious AE & 9 & 1198 & 430 & 34.5 & $28.1-41.6$ & $<0.001$ & 82.6 \\
\hline Any Grade 3/4 AE & 8 & 1147 & 751 & 64.0 & $47.1-78.0$ & $<0.001$ & 96.1 \\
\hline Diarrhea & 15 & 2005 & 1133 & 54.4 & $40.5-67.6$ & $<0.001$ & 96.5 \\
\hline Diarrhea 3/4 & 15 & 2005 & 49 & 2.6 & $1.6-4.2$ & 0.013 & 50.7 \\
\hline Nausea & 15 & 2005 & 1087 & 51.5 & $29.5-63.3$ & $<0.001$ & 95.8 \\
\hline Nausea 3/4 & 15 & 2005 & 53 & 2.5 & $1.6-4.1$ & 0.003 & 56.9 \\
\hline Vomiting & 15 & 2005 & 852 & 38.3 & $29.1-48.3$ & $<0.001$ & 94.3 \\
\hline Vomiting 3/4 & 15 & 2005 & 51 & 2.7 & $1.8-4.2$ & 0.025 & 46.4 \\
\hline Constipation & 14 & 1973 & 618 & 31.0 & $26.5-35.8$ & $<0.001$ & 79.7 \\
\hline Constipation 3/4 & 14 & 1973 & 12 & 1.2 & $0.7-1.9$ & 0.68 & 0.0 \\
\hline Fatigue & 14 & 1901 & 533 & 27.2 & $22.9-31.9$ & $<0.001$ & 78.8 \\
\hline Fatigue $3 / 4$ & 14 & 1901 & 54 & 3.2 & $2.0-5.0$ & 0.004 & 57.7 \\
\hline ALT & 12 & 1552 & 502 & 28.2 & $19.8-38.3$ & $<0.001$ & 93.5 \\
\hline ALT 3/4 & 12 & 1552 & 239 & 11.1 & $7.1-16.9$ & $<0.001$ & 89.4 \\
\hline AST & 13 & 1662 & 447 & 24.8 & $18.3-32.5$ & $<0.001$ & 90.7 \\
\hline AST 3/4 & 13 & 1662 & 125 & 6.8 & $4.6-9.9$ & $<0.001$ & 74.5 \\
\hline QTe & 5 & 477 & 40 & 8.6 & $4.9-14.8$ & 0.04 & 60.1 \\
\hline QTe 3/4 & 11 & 1558 & 28 & 2.1 & $1.2-3.6$ & 0.061 & 43.4 \\
\hline ILD & 9 & 1255 & 26 & 2.2 & $1.2-4.0$ & 0.04 & 50.5 \\
\hline ILD 3/4 & 10 & 1346 & 17 & 1.9 & $1.2-3.0$ & 0.54 & 0 \\
\hline
\end{tabular}

Abbreviations: $\mathrm{AE}=$ Adverse Event; ALT = Alanine Aminotransferase; AST = Aspartate Aminotransferase; ILD = Interstial Lung Disease.

"Meta-analyses were conducted using one-sample proportions to obtain random effects, estimates of toxicity rates and $95 \%$ confidence intervals. Heterogeneity was assessed by the $Q$ chi square statistic. $p \leq 0.05$ was considered statistically significant.

The percent of total variance for study heterogeneity was estimated using the I squared $\left(\mathrm{I}^{2}\right)$ statistic. Analyses were conducted using Comprehensive MetaAnalysis software package (Comprehensive Meta-Analysis, Version 3.3.070, 2014, Biostatic; Englewood NJ).

almost all of the 15 reports included in this analysis. The AR for all-grade fatigue was $27.2 \%$ with an AR for grade $3 / 4$ fatigue of $3.2 \%$. Despite being considered significant toxicities, all-grade and grade $3 / 4 \mathrm{QTcB}$ prolongation and ILD were only described in five and nine out of the 15 studies, respectively. The risk for grade $3 / 4 \mathrm{QTcB}$ prolongation was $2.1 \%$. These two rates are in line with a recent meta-analysis that showed incidences of highgrade ILD and QTcB prolongation of $2.5 \%$ and $2.8 \%$, respectively [29].

Important differences were detected amongst the different $A L K$ inhibitors likely due to off-target effects with these drugs. Ceritinib had a high AR of GI toxicity, namely diarrhea, nausea, and vomiting. A plausible explanation is that Ceritinib inhibits the activity of insulin growth factor receptor (IGFR), which is expressed in cells alongside the GI tract in pre-clinical models [6, 7]. Early trials with IGFR inhibitors such as cixutumumab did report GI toxicities such as abdominal pain, nausea, vomiting, diarrhea in different dose escalation cohorts [30, 31]. In preclinical models, EGFR inhibition in repairing airway epithelial cells modulated significant expression of genes involved in the airway microenvironment, prolonged inflammation, and potentiated acute lung injury [32]. Therefore, this may be a plausible explanation for pneumonitis in the early studies with Brigatinib as it inhibits EGFR kinases [33]. Experimental models suggest that ALK inhibitors might target retinal ganglion cells affecting response to light. The drug potency on the these responses might be responsible for the difference in the frequencies of visual disturbances between crizotinib and alectinib [34]. Crizotinib, first-in-class amongst the $A L K$ and ROS inhibitors, is still a very effective and safe option for the treatment of patients with $A L K$ positive metastatic NSCLC, a condition associated with a poor prognosis and for which limited therapeutic options exist. In a recent meta-analysis, diarrhea, nausea, vomiting, peripheral edema, and constipation were amongst the most common side effects related to Crizotinib [35]. The overall rate of SAEs with Crizotinib was 19.9\% in another systematic review [36]. Grade 3 to 5 adverse events occurred at a rate of $50 \%$ with Crizotinib versus $41 \%$ with Alectinib in the 
Table 3: Adverse events (\%) by treatment drug (included trials)

\begin{tabular}{lccccc}
\hline AE & Alectinib & Brigatinib & Ceritinib & Crizotinib & $\boldsymbol{p}_{\text {-value }}$ \\
\hline Any AE (\%) & 96.7 & $\mathrm{ND}$ & 99.6 & 97.7 & 0.022 \\
Any Serious AE (\%) & 21.6 & $\mathrm{ND}$ & 44.9 & 31.1 & $<0.001$ \\
Any Grade 3/4 AE (\%) & $\mathrm{ND}$ & $\mathrm{ND}$ & 75.3 & 43.4 & 0.009 \\
Diarrhea (\%) & 13.7 & 38.2 & 81.2 & 56.0 & $<0.001$ \\
Diarrhea 3/4 (\%) & 0.6 & 0.5 & 5.6 & 1.7 & $<0.001$ \\
Nausea (\%) & 15.3 & 40.0 & 73.9 & 55.3 & $<0.001$ \\
Nausea 3/4 (\%) & 0.5 & 0.9 & 5.7 & 1.8 & $<0.001$ \\
Vomiting (\%) & 9.8 & 22.7 & 60.4 & 43.9 & $<0.001$ \\
Vomiting 3/4 (\%) & 0.6 & 0.5 & 5.2 & 2.0 & $<0.001$ \\
Constipation (\%) & 34.1 & 15.5 & 24.3 & 37.1 & $<0.001$ \\
Constipation 3/4 (\%) & 0.4 & 0.5 & 0.8 & 1.5 & 0.37 \\
Fatigue (\%) & 25.7 & 27.3 & 34.5 & 21.7 & 0.039 \\
Fatigue 3/4 (\%) & 1.0 & 0.5 & 6.0 & 2.1 & $<0.001$ \\
ALT (\%) & 14.3 & ND & 46.9 & 21.8 & $<0.001$ \\
ALT 3/4 (\%) & 4.0 & ND & 22.8 & 9.1 & $<0.001$ \\
AST (\%) & 15.0 & 14.5 & 38.8 & 21.0 & $<0.001$ \\
AST 3/4 (\%) & 3.9 & 0.5 & 11.4 & 5.7 & 0.007 \\
QT (\%) & 1.2 & ND & 9.0 & 14.4 & 0.025 \\
QT 3/4 (\%) & 0.8 & ND & 0.9 & 3.9 & 0.003 \\
ILD (\%) & 0.6 & ND & 2.4 & 2.4 & 0.610 \\
ILD 3/4 (\%) & 0.4 & ND & 2.1 & 2.0 & 0.310 \\
\hline Abbrvis & & & \\
\hline
\end{tabular}

Abbreviations: $\mathrm{AE}=$ Adverse Event; ALT = Alanine Aminotransferase; $\mathrm{AST}=$ Aspartate Aminotransferase; ILD = Interstial Lung Disease; ND = No data available;

"Heterogeneity across treatment was assessed using the between-group $Q$ statistic, $p \leq 0.05$ was considered statistically significant.

Alex study [14]. In keeping with these reports, the AR of serious and grade $3 / 4$ AEs were $31 \%$ and $43 \%$. Nausea, vomiting, and diarrhea were very common in our analysis.

Alectinib is now considered the preferred first-line agent for $A L K$ positive metastatic NSCLC patients. A recent pooled analysis from the two pivotal phase 2 trials using Alectinib $600 \mathrm{mg}$ twice daily again confirmed an acceptable safety profile with continued follow-up. Grade 3 or higher AEs occurred at a rate of $40 \%$. The rate of discontinuation of treatment due to AEs was 6\%. Dose interruption and/or modification occurred at a rate of $33 \%$. In this analysis, the AR of serious $\mathrm{AE}$ was approximately $22 \%$. The AR for Grade 3/4 diarrhea, nausea, vomiting and constipation was below $1 \%$ for any of these AEs [36].

Ceritinib may also be used in the first or subsequent lines of therapy for $A L K$ positive metastatic NSCLC. In preclinical models, it has been shown to be a more potent ALK inhibitor than Crizotinib [37]. However, it has not been directly compared to the first-in-class compound in the first-line or subsequent-line settings. No phase 3 randomized controlled trials comparing these two drugs are being planned or conducted. In this analysis, Ceritinib stands out as having the highest AR of GI toxicities which may hamper its usage in clinical practice. Therefore, it would be important to conceive a strategy to mitigate GI toxicity given its proven efficacy. Results of part 1 of the phase 1 ASCEND 8 trial suggest that Ceritinib may be taken at lower doses (e.g., $450 \mathrm{mg}$ daily, $600 \mathrm{mg}$ daily) with a low-fat meal. At steady state, the 450-mg dose with food demonstrated comparable pharmacokinetics (PK) as assessed by peak concentration of the drug in plasma and area under the curve from 0 to 24 hours. The 600-mg dose with food demonstrated approximately $25 \%$ higher PK. The 450-mg dose with food was associated with a lower proportion of patients with GI toxicities: diarrhea, nausea, and vomiting. There were no grade 3 or 4 AEs, 
study drug discontinuations, or serious AEs due to GI toxicities. Efficacy and long-term safety results will be available once part 2 is concluded [38]. If confirmed, physicians along with patients may feel more confident about the safety of Ceritinib with this strategy.

Brigatinib is another potent $A L K$ inhibitor that has demonstrated activity against many $A L K$ domain mutations giving rise to resistance to other drugs in the same class. Pre-clinical data have shown increased potency of Brigatinib as compared to Crizotinib [7]. It has been shown to have promising systemic and intracranial activity and an acceptable safety profile for the $A L K$ rearranged NSCLC subset [16, 39]. Early pulmonary AEs occurred at $90 \mathrm{mg}$ with no further events occurring after escalation to $180 \mathrm{mg}$. Therefore, a lead-in dose of $90 \mathrm{mg}$ once daily for 1 week before escalation to $180 \mathrm{mg}$ once daily was chosen for further development [39]. A Phase 3 global clinical Trial (ALTA1L) comparing Crizotinib and Brigatinib in the setting $A L K$-TKI naïve metastatic is ongoing and currently accruing patients (NCT02737501).

The lack of access to individual patient data is the major limitation of this study and does not allow for exploration of correlations between patient characteristics and risk of toxicities. Data on adverse events were missing for several reports. The lack of consistency on how AEs are reported makes it difficult to compare AEs amongst the different studies. For example, in the ALEX study, grade $\geq 3$ events were grouped as grade 3-5 events in contrast to the other studies in this analysis where grade $\geq 3$ events were grouped as grade 3-4 events. The JALEX trial used a dose of Alectinib of $300 \mathrm{mg}$ Twice Daily and therefore, data from that arm was excluded from our report. The phase I dose finding trial and the 90-mg dose of other studies using Brigatinib were also excluded from this analysis. The only arm used here was the $180-\mathrm{mg}$ arm for Brigatinib with a lead in dose schedule of $90 \mathrm{mg}$ daily for 7 days prior to the approved dose. This may have contributed to a low rate of ILD reported in this analysis.

In the early phase trials, responses were seen at lower doses of $A L K$ inhibitors. Shaw et al showed an AR of Grade 3/4 AE of $20 \%$ in patients taking 5-300 mg of Ceritinib daily. There was no case of Grade3/4 diarrhea, nausea or vomiting. Partial responses were confirmed in two out of eight patients in that cohort [40]. Grade 3 AEs were reported in $37 \%$ of patients in a phase I-II trial conducted in Japan in patients using Alectinib 300 $\mathrm{mg}$ twice daily. No grade 4 AEs or deaths were reported. No cases of grade 3 nausea, diarrhea, or vomiting were reported [41]. Thus, using lower doses of an $A L K$ inhibitor may mitigate toxicity without compromising efficacy.

\section{CONCLUSIONS}

$A L K$ inhibitors have an acceptable safety profile with a low risk of treatment-related deaths. Important differences in toxicity profile were detected amongst the different $A L K$ inhibitors. Physicians have several options for the treatment of patients with this distinct molecular subgroup of NSCLC.

\section{CONFLICTS OF INTEREST}

The authors declare no conflicts of interest related to the publication of this manuscript.

\section{REFERENCES}

1. Dearden S, Stevens J, Wu YL, Blowers D. Mutation incidence and coincidence in non small-cell lung cancer: meta-analyses by ethnicity and histology (mutMap). Ann Oncol. 2013; 24:2371-6. https://doi.org/10.1093/annonc/ mdt205.

2. Gainor JF, Shaw AT. Novel targets in non-small cell lung cancer: ROS1 and RET fusions. Oncologist. 2013; 18:86575. https://doi.org/10.1634/theoncologist.2013-0095.

3. Solomon BJ, Mok T, Kim DW, Wu YL, Nakagawa K, Mekhail T, Felip E, Cappuzzo F, Paolini J, Usari T, Iyer $\mathrm{S}$, Reisman A, Wilner KD, et al. First-line crizotinib versus chemotherapy in ALK-positive lung cancer. N Engl J Med. 2014; 371:2167-77. https://doi.org/10.1056/ NEJMoa1408440.

4. Shaw AT, Kim DW, Nakagawa K, Seto T, Crinó L, Ahn MJ, De Pas T, Besse B, Solomon BJ, Blackhall F, Wu YL, Thomas M, O'Byrne KJ, et al. Crizotinib versus chemotherapy in advanced ALK-positive lung cancer. N Engl J Med. 2013; 368:2385-94. https://doi.org/10.1056/ NEJMoa1214886.

5. Soria JC, Tan D, Chiari R, Wu YL, Paz-Ares L, Wolf J, Geater S, Orlov S, Cortinovis D, Yu CJ, Hochmair M, Cortot A, Tsai CM, et al. First-line ceritinib versus platinum-bas ed chemotherapy in advanced ALK-rearranged non-small-cell lung cancer (ASCEND-4): a randomised, open-label, phase 3 study. Lancet. 2017; 389:917-929.

6. Marsilje TH, Pei W, Chen B, Lu W, Uno T, Jin Y, Jiang T, Kim S, Li N, Warmuth M, Sarkisova Y, Sun F, Steffy A, et al. Synthesis, structure-activity relationships, and in vivo efficacy of the novel potent and selective anaplastic lymphoma kinase (ALK) inhibitor 5-chloro-N2-(2-isopropoxy-5-methyl-4(piperidin-4-yl)phenyl)-N4-(2-(isopropylsulf onyl)phenyl) pyrimidine-2,4-diamine (LDK378) currently in phase 1 and phase 2 clinical trials. J Med Chem. 2013; 56:5675-90. https://doi.org/10.1021/jm400402q.

7. Sabari JK, Santini FC, Schram AM, Bergagnini I, Chen R, Mrad C, Lai WV, Arbour KC, Drilon A. The activity, safety, and evolving role of brigatinib in patients with ALKrearranged non-small cell lung cancers. Onco Targets Ther. 2017; 10:1983-92. https://doi.org/10.2147/ott.s109295.

8. Camidge DR, Bang YJ, Kwak EL, Iafrate AJ, VarellaGarcia M, Fox SB, Riely GJ, Solomon B, Ou SH, Kim DW, Salgia R, Fidias P, Engelman JA, et al. Activity and safety 
of crizotinib in patients with ALK-positive non-small-cell lung cancer: updated results from a phase 1 study. Lancet Oncol. 2012; 13:1011-9. https://doi.org/10.1016/s14702045(12)70344-3.

9. Kim DW, Mehra R, Tan DS, Felip E, Chow LQ, Camidge DR, Vansteenkiste J, Sharma S, De Pas T, Riely GJ, Solomon BJ, Wolf J, Thomas M, et al. Activity and safety of ceritinib in patients with ALK-rearranged non-small-cell lung cancer (ASCEND-1): updated results from the multicentre, openlabel, phase 1 trial. Lancet Oncol. 2016; 17:452-63. https:// doi.org/10.1016/s1470-2045(15)00614-2.

10. Crinò L, Ahn MJ, De Marinis F, Groen HJM, Wakelee H, Hida T, Mok T, Spigel D, Felip E, Nishio M, Scagliotti G, Branle F, Emeremni C, et al. Multicenter phase II study of whole-body and intracranial activity with ceritinib in patients with ALK-rearranged non-small-cell lung cancer previously treated with chemotherapy and crizotinib: Results from ASCEND-2. J Clin Oncol. 2016; 34:2866-73. https://doi.org/10.1200/JCO.2015.65.5936.

11. Shaw AT, Kim TM, Crinò L, Gridelli C, Kiura K, Liu G, Novello S, Bearz A, Gautschi O, Mok T, Nishio M, Scagliotti G, Spigel DR, et al. Ceritinib versus chemotherapy in patients with ALK-rearranged nonsmall-cell lung cancer previously given chemotherapy and crizotinib (ASCEND-5): A randomised, controlled, open-label, phase 3 trial. Lancet Oncol. 2017; 18:874-886. https://doi.org/10.1016/S1470-2045(17)30339-X.

12. Ou SH, Ahn JS, De Petris L, Govindan R, Yang JC, Hughes B, Lena H, Moro-Sibilot D, Bearz A, Ramirez SV, Mekhail T, Spira A, Bordogna W, et al. Alectinib in Crizotinib-Refractory ALKRearranged Non-Small-Cell Lung Cancer: A Phase II Global Study. J Clin Oncol. 2016; 34:661-8. https://doi.org/10.1200/ jco.2015.63.944310.1200/jco.2016.34.4_suppl.661.

13. Shaw AT, Gandhi L, Gadgeel S, Riely GJ, Cetnar J, West H, Camidge DR, Socinski MA, Chiappori A, Mekhail T, Chao BH, Borghaei H, Gold KA, et al. Alectinib in ALK-positive, crizotinib-resistant, non-small-cell lung cancer: A single-group, multicentre, phase 2 trial. Lancet Oncol. 2016; 17:234-42. https://doi.org/10.1016/S14702045(15)00488-X.

14. Peters S, Camidge DR, Shaw AT, Gadgeel S, Ahn JS, Kim DW, Ou SI, Perol M, Dziadziuszko R, Rosell R, Zeaiter A, Mitry E, Golding S, et al. Alectinib versus Crizotinib in Untreated ALK-Positive Non-Small-Cell Lung Cancer. N Engl J Med. 2017; 377:829-838. https://doi.org/10.1056/ NEJMoa1704795.

15. Hida T, Nokihara H, Kondo M, Kim YH, Azuma K, Seto T, Takiguchi Y, Nishio M, Yoshioka H, Imamura F, Hotta $\mathrm{K}$, Watanabe S, Goto K, et al. Alectinib versus crizotinib in patients with ALK-positive non-small-cell lung cancer (J-ALEX): an open-label, randomised phase 3 trial. Lancet. 2017; 390:29-39. https://doi.org/10.1016/s01406736(17)30565-2.

16. Kim DW, Tiseo M, Ahn MJ, Reckamp KL, Hansen KH, Kim SW, Huber RM, West HL, Groen HJM, Hochmair
MJ, Leighl NB, Gettinger SN, Langer CJ, et al. Brigatinib in Patients With Crizotinib-Refractory Anaplastic Lymphoma Kinase-Positive Non-Small-Cell Lung Cancer: A Randomized, Multicenter Phase II Trial. J Clin Oncol. 2017:Jco2016715904. https://doi.org/10.1200/ jco.2016.71.5904.

17. Itchins M, Chia PL, Hayes SA, Howell VM, Gill AJ, Cooper WA, John T, Mitchell P, Millward M, Clarke SJ, Solomon B, Pavlakis N. Treatment of ALK-rearranged non-small cell lung cancer: A review of the landscape and approach to emerging patterns of treatment resistance in the Australian context. Asia Pac J Clin Oncol. 2017; 13:3-13. https://doi. org/10.1111/ajco.12754.

18. Chin LP, Soo RA, Soong R, Ou SH. Targeting ROS1 with anaplastic lymphoma kinase inhibitors: A promising therapeutic strategy for a newly defined molecular subset of non-small-cell lung cancer. Journal of Thoracic Oncology. 2012; 7:1625-30. https://doi.org/10.1097/ JTO.0b013e31826baf83.

19. Yasuda H, de Figueiredo-Pontes LL, Kobayashi S, Costa DB. Preclinical rationale for use of the clinically available multitargeted tyrosine kinase inhibitor crizotinib in ROS1translocated lung cancer. J Thorac Oncol. 2012; 7:1086-90. https://doi.org/10.1097/JTO.0b013e3182570919.

20. Shaw AT, Ou SH, Bang YJ, Camidge DR, Solomon BJ, Salgia R, Riely GJ, Varella-Garcia M, Shapiro GI, Costa DB, Doebele RC, Le LP, Zheng Z, et al. Crizotinib in ROS1rearranged non-small-cell lung cancer. N Engl J Med. 2014; 371:1963-71. https://doi.org/10.1056/NEJMoa1406766.

21. Lim SM, Kim HR, Lee JS, Lee KH, Lee YG, Min YJ, Cho EK, Lee SS, Kim BS, Choi MY, Shim HS, Chung JH, La Choi Y, et al. Open-Label, Multicenter, Phase II Study of Ceritinib in Patients With Non-Small-Cell Lung Cancer Harboring ROS1 Rearrangement. J Clin Oncol. 2017; 35:2613-2618. https://doi.org/10.1200/jco.2016.71.3701.

22. Zhang L, Jiang T, Zhao C, Li W, Li X, Zhao S, Liu X, Jia Y, Yang H, Ren S, Zhou C. Efficacy of crizotinib and pemetrexed-based chemotherapy in Chinese NSCLC patients with ROS1 rearrangement. Oncotarget. 2016; 7:75145-54. https://doi.org/10.18632/oncotarget.12612.

23. Network NCC. Non-Small Cell Lung Cancer (Version 8.2017).

24. Liberati A, Altman DG, Tetzlaff J, Mulrow C, Gotzsche PC, Ioannidis JP, Clarke M, Devereaux PJ, Kleijnen J, Moher D. The PRISMA statement for reporting systematic reviews and meta-analyses of studies that evaluate healthcare interventions: explanation and elaboration. BMJ. 2009; 339:b2700. https://doi.org/10.1136/bmj.b2700.

25. Moher D, Liberati A, Tetzlaff J, Altman DG; PRISMA Group. Preferred reporting items for systematic reviews and meta-analyses: the PRISMA statement. Ann Intern Med. 2009; 151:264-9, W64.

26. Kamoi M, Noye Y. Graphical method of chi-square test. A statistical method for public health investigation. Tohoku J Exp Med. 1959; 71:27-40. 
27. Lalim an V, Roïz J. Frequentist Approach for Detecting Heterogeneity in Meta-Analysis Pair-Wise Comparisons: Enhanced Q-Test Use By Using I2 and H2 Statistics. Value Health. 2014; 17:A576. https://doi.org/10.1016/j. jval.2014.08.1942.

28. Egger M, Davey Smith G, Schneider M, Minder C. Bias in meta-analysis detected by a simple, graphical test. BMJ. 1997; 315:629-34.

29. Lin L, Zhao J, Kong N, He Y, Hu J, Huang F, Hanan J, Cao X. Meta-analysis of the incidence and risks of interstitial lung disease and QTc prolongation in nonsmall-cell lung cancer patients treated with ALK inhibitors. Oncotarget. 2017; 8:57379-85. https://doi.org/10.18632/ oncotarget. 18283.

30. Doi T, Shitara K, Kojima T, Yoshino T, Dontabhaktuni A, Rebscher H, Tang S, Cosaert J, Ohtsu A. A phase I study evaluating cixutumumab, a type 1 insulin-like growth factor receptor inhibitor, given every 2 or 3 weeks in Japanese patients with advanced solid tumors. Cancer Chemother Pharmacol. 2016; 77:1253-62. https://doi.org/10.1007/ s00280-016-3041-7.

31. Higano CS, Berlin J, Gordon M, LoRusso P, Tang S, Dontabhaktuni A, Schwartz JD, Cosaert J, Mehnert JM. Safety, tolerability, and pharmacokinetics of single and multiple doses of intravenous cixutumumab (IMC-A12), an inhibitor of the insulin-like growth factor-I receptor, administered weekly or every 2 weeks in patients with advanced solid tumors. Invest New Drugs. 2015; 33:450 62. https://doi.org/10.1007/s10637-015-0217-7.

32. Harada C, Kawaguchi T, Ogata-Suetsugu S, Yamada M, Hamada N, Maeyama T, Souzaki R, Tajiri T, Taguchi T, Kuwano K, Nakanishi Y. EGFR tyrosine kinase inhibition worsens acute lung injury in mice with repairing airway epithelium. Am J Respir Crit Care Med. 2011; 183:743-51. https://doi.org/10.1164/rccm.201002-0188OC.

33. Zhang S, Anjum R, Squillace R, Nadworny S, Zhou T, Keats J, Ning Y, Wardwell SD, Miller D, Song Y, Eichinger L, Moran L, Huang WS, et al. The Potent ALK Inhibitor Brigatinib (AP26113) Overcomes Mechanisms of Resistance to First- and Second-Generation ALK Inhibitors in Preclinical Models. Clin Cancer Res. 2016; 22:5527-38. https://doi.org/10.1158/1078-0432.CCR-16-0569.

34. Ishii T, Iwasawa S, Kurimoto R, Maeda A, Takiguchi Y, Kaneda M. Crizotinib-Induced Abnormal Signal Processing in the Retina. PLoS One. 2015; 10:e0135521. https://doi. org/10.1371/journal.pone.0135521.
35. Li G, Dai WR, Shao FC. Effect of ALK-inhibitors in the treatment of non-small cell lung cancer: a systematic review and meta-analysis. Eur Rev Med Pharmacol Sci. 2017; 21:3496-503.

36. Zhu Q, Hu H, Jiang F, Guo CY, Yang XW, Liu X, Kuang YK. Meta-analysis of incidence and risk of severe adverse events and fatal adverse events with crizotinib monotherapy in patients with ALK-positive NSCLC. Oncotarget. 2017; 8:75372-75380. https://doi.org/10.18632/oncotarget.18536.

37. Mok TSK, Crino L, Felip E, Salgia R, De Pas T, Tan DSW, Chow LQM. The accelerated path of ceritinib: Translating pre-clinical development into clinical efficacy. Cancer Treat Rev. 2017; 55:181-9. https://doi.org/10.1016/j. ctrv.2017.03.006.

38. Cho BC, Kim DW, Bearz A, Laurie SA, McKeage M, Borra G, Park K, Kim SW, Ghosn M, Ardizzoni A, Maiello E, Greystoke A, Yu R, et al. ASCEND-8: A Randomized Phase 1 Study of Ceritinib, $450 \mathrm{mg}$ or $600 \mathrm{mg}$, Taken with a Low-Fat Meal versus $750 \mathrm{mg}$ in Fasted State in Patients with Anaplastic Lymphoma Kinase (ALK)-Rearranged Metastatic Non-Small Cell Lung Cancer (NSCLC). J Thorac Oncol. 2017; 12:1357-67. https://doi.org/10.1016/j. jtho.2017.07.005.

39. Gettinger SN, Bazhenova LA, Langer CJ, Salgia R, Gold KA, Rosell R, Shaw AT, Weiss GJ, Tugnait M, Narasimhan NI, Dorer DJ, Kerstein D, Rivera VM, et al. Activity and safety of brigatinib in ALK-rearranged non-small-cell lung cancer and other malignancies: a single-arm, open-label, phase 1/2 trial. Lancet Oncol. 2016; 17:1683-96. https:// doi.org/10.1016/S1470-2045(16)30392-8.

40. Shaw AT, Kim DW, Mehra R, Tan DSW, Felip E, Chow LQM, Camidge DR, Vansteenkiste J, Sharma S, De Pas T, Riely GJ, Solomon BJ, Wolf J, et al. Ceritinib in ALKrearranged non-small-cell lung cancer. N Engl J Med. 2014; 370:1189-97. https://doi.org/10.1056/NEJMoa1311107.

41. Seto T, Kiura K, Nishio M, Nakagawa K, Maemondo M, Inoue A, Hida T, Yamamoto N, Yoshioka H, Harada M, Ohe Y, Nogami N, Takeuchi K, et al. CH5424802 (RO5424802) for patients with ALK-rearranged advanced non-small-cell lung cancer (AF-001JP study): a single-arm, open-label, phase 1-2 study. Lancet Oncol. 2013; 14:590-8. https://doi. org/10.1016/S1470-2045(13)70142-6. 